\title{
Conjugated linoleic acid decreases fat accretion in pigs: evaluation by dual-energy X-ray absorptiometry
}

\author{
Ewa Ostrowska ${ }^{1}$, Danny Suster ${ }^{1}$, Morley Muralitharan ${ }^{2}$, Reg F. Cross ${ }^{3}$, Brian J. Leury ${ }^{4}$, \\ Dale E. Bauman ${ }^{5}$ and Frank R. Dunshea ${ }^{1 *}$ \\ ${ }^{1}$ Agriculture Victoria, Victorian Institute of Animal Science, 600 Sneydes Road, Werribee, VIC 3030, Australia \\ ${ }^{2}$ Deakin University, Geelong, Victoria, Australia \\ ${ }^{3}$ Swinburne University of Technology, Hawthorn, VIC 3122, Australia \\ ${ }^{4}$ The University of Melbourne, Melbourne, 3010, Australia \\ ${ }^{5}$ Cornell University, Ithaca, NY 14853, USA
}

(Received 11 December 2001 - Revised 13 August 2002 - Accepted 22 September 2002)

\begin{abstract}
Thirty female Large White $\times$ Landrace pigs (average weight 57.2 (SD 1.9) $\mathrm{kg}$ ) were allocated to one of six dietary treatments containing $0,1 \cdot 25,2 \cdot 5,5 \cdot 0,7 \cdot 5$ or $10.0 \mathrm{~g} 55 \%$ conjugated linoleic acids (CLA) isomers (CLA-55)/kg diet and fed for 8 weeks. Each pig was scanned at 0, 28 and $56 \mathrm{~d}$ and again at post slaughter using dual-energy X-ray absorptiometry (DXA) to determine the temporal pattern of body composition responses. Values determined by DXA were adjusted using regression equations generated from validation experiments between chemically and DXA-predicted values. Overall, there was a significant linear reduction in fat content with the increasing levels of CLA in the diet $(P=0.007, P=0.011, P=0.008$ at week 4 , week 8 and for the carcass, respectively). The greatest improvement was recorded at the early stages of CLA supplementation and for the highest dose of CLA (week 4, - 19.2\% compared with week $8,-13.7 \%$ ). In the first 4 weeks of feeding CLA, pigs receiving $10 \mathrm{~g}$ CLA-55/kg diet deposited $93 \mathrm{~g}$ less fat/d than pigs fed basal diets $(P=0.002)$ compared with only $6 \mathrm{~g}$ less fat than control animals in the final 4 weeks. Lean content and lean deposition rate were maximised at 5 and $2.5 \mathrm{~g} \mathrm{CLA}-55 / \mathrm{kg}$ diet for the first 4 weeks $(P=0.016)$ and the final 4 weeks of treatment $(P=0 \cdot 17)$, respectively. DXA estimates of bone mineral content and bone mineral density were not affected by CLA supplementation throughout the experiment. These data demonstrate that dietary CLA decreases body fat in a dose-dependent manner and that the response is greatest over the initial 4 weeks of treatment.
\end{abstract}

Conjugated linoleic acid: Dual-energy X-ray absorptiometry: Body composition: Pig

Conjugated linoleic acid (CLA) represents a mixture of positional and geometric isomers $(18: 2 n-6)$ of linoleic acid with conjugated double bonds located at positions 7,9-, 8,10-, 9,11-, 10,12- or 11,13- on the C chain. CLA exerts many positive health effects in experimental models including anticarcinogenic and anti-tumorogenic as well as anti-atherogenic and antidiabetogenic properties (for reviews, see Whigham et al. 2000; Pariza et al. 2001). Another biological effect of CLA relates to fat accretion and nutrient partitioning. Dietary CLA supplementation reduces body fat mass in rodents (Chin et al. 1994; Park et al. 1995; DeLany et al. 1999) and pigs (Ostrowska et al. 1999). These findings were based on experiments involving slaughter and subsequent chemical analysis in which the ultimate rates of change in body composition were determined at the conclusion of CLA supplementation. However, little is known about the longitudinal effects of CLA supplementation on body composition and generation of such data requires killing large numbers of animals at various stages of development. Alternatively, body composition can be measured in live animals and carcasses using dual-energy X-ray absorptiometry (DXA) (Mitchell et al. 1998; Lukaski et al. 1999; Suster et al. 2000), which is non-invasive and allows longitudinal studies in the same animal. The DXA apparatus can be used to analyse the fat, lean and bone mineral content (BMC) of the whole animal and is also capable of measuring the regional distribution of these tissues (Mitchell et al.

\footnotetext{
Abbreviations: BMC, bone mineral content; CLA, conjugated linoleic acid; DXA, dual-energy X-ray absorptiometry; FCE, feed conversion efficiency; $\mathrm{R}_{\mathrm{F}}$, attenuation of pure fat; $\mathrm{R}_{\mathrm{L}}$, attenuation of bone-free lean tissue; $\mathrm{R}_{\mathrm{ST}}$, ratio of soft tissue attenuation.

* Corresponding author: Associate Professor Frank R. Dunshea, fax +61 39742 0400, email Frank.Dunshea@nre.vic.gov.au
} 
1996; Suster et al. 2001). The aim of the present study was to utilise DXA technology to validate the effectiveness of CLA supplementation in pigs and to generate more comprehensive data on the progressive change in body composition in growing and finisher pigs fed different levels of dietary CLA.

\section{Materials and methods}

\section{Animals and handling}

All procedures involving animals were approved by the Victorian Institute of Animal Science Animal Ethics Committee (Anonymous, 1997). Thirty-five (Large White $\times$ Landrace) pigs were used in the experiment. To obtain initial body composition by chemical analysis, five pigs were killed (after an in vivo DXA scan; see p. 220) at the beginning of the experiment. The remaining thirty pigs were randomly allocated to one of six dietary treatments $(0,1.25,2 \cdot 5,5.0,7.5$ or $10.0 \mathrm{~g}$ CLA-55/kg diet (Natural Lipids Ltd., Hovdebygda, Norway). The CLA used in the present study contained $55 \%$ (w/w) CLA isomers and was prepared from sunflower-seed oil. Therefore, the CLA concentrations for the six diets were $0,0.7$, $1.4,2 \cdot 75,4.1$ and $5.5 \mathrm{~g} / \mathrm{kg}$ diet, respectively. The CLA content of the supplement and diets was measured by HPLC (Cross et al. 2000; Ostrowska et al. 2000). The CLA-55 mixture consisted of $13.8 \%$ trans $/$ cis- $8,10,24.5 \%$ cis/ trans $-9,11,30.5 \%$ trans $/$ cis- 10,12 and $18.3 \%$ cis/trans11,3 isomers present in a non-esterified fatty acid form. The remainder of the CLA-55 mixture consisted of small amounts of cis, cis and trans, trans isomers.

Pigs were initially blocked into groups of six pigs with an average live weight of 57.2 (SD 1.9) $\mathrm{kg}$ and P2 back fat (65 $\mathrm{mm}$ from the midline over the last rib) thickness of 11.5 (SD 1.3) $\mathrm{mm}$. The experimental diets (Table 1) were formulated to contain 14.3 MJ digestible energy, 9.3 g lysine and $175 \mathrm{~g}$ crude protein $/ \mathrm{kg}$ air-dry diet, which was in excess of protein and lysine requirements for the class of pig used in the study (Dunshea et al. 1993). Amino acid content relative to lysine was kept in excess of the amino acid balance proposed as ideal by the Standing Committee on Agriculture (1987) to ensure that lysine was the first limiting amino acid. Diets were fed ad libitum for 8 weeks and unlimited access to water was provided via nipple drinkers. Pigs were individually housed to allow individual feed intake and live-weight measurements to be made weekly.

\section{Dual-energy $X$-ray absorptiometry scans}

Total whole body DXA scans were performed using a Hologic QDR 4500A Fan Beam X-Ray Bone Densitometer (Hologic, Inc., Waltham, MA) equipped with the body composition option software. The software calculates the ratio of soft tissue attenuation $\left(\mathrm{R}_{\mathrm{ST}}\right)$ of the low- and high-energy beams as they pass through the body. The attenuations of pure fat $\left(\mathrm{R}_{\mathrm{F}}\right)$ and of bone-free lean tissue $\left(\mathrm{R}_{\mathrm{L}}\right)$ are known from theoretical calculation and in vitro measurements. Thus, an equation for each X-ray energy level with two unknown factors can be solved to calculate the proportion of fat $(\infty)$ and lean tissue $(\beta)$ in each pixel containing soft tissue only (Hologic, Inc.):

$$
\begin{aligned}
& R_{S T}\left(\text { low energy) }=\infty\left(R_{F}\right)+\beta\left(R_{L}\right),\right. \\
& R_{S T}\left(\text { high energy) }=\infty\left(R_{F}\right)+\beta\left(R_{L}\right) .\right.
\end{aligned}
$$

On each scanning day, the unit was calibrated according to the manufacturer's specifications to ensure accurate fat and lean composition results, for accurate BMC measurement and to minimise baseline drift. Pigs were scanned at the beginning of the experiment, after 4 weeks and again at the conclusion of the experiment (after 8 weeks). Pigs were fasted for $16 \mathrm{~h}$ before scanning to minimise errors associated with water in the gut lumen. Fasted pigs were also weighed before scanning to assist with unit calibration.

\begin{tabular}{|c|c|c|c|c|c|c|}
\hline \multirow[b]{2}{*}{ Ingredients } & \multicolumn{6}{|c|}{ Dose of CLA-55 (g/kg diet) } \\
\hline & 0 & $1 \cdot 25$ & 2.5 & $5 \cdot 0$ & $7 \cdot 5$ & $10 \cdot 0$ \\
\hline Wheat & $691 \cdot 74$ & $691 \cdot 74$ & $691 \cdot 74$ & $691 \cdot 74$ & $691 \cdot 74$ & $691 \cdot 74$ \\
\hline Soyabean meal & $121 \cdot 61$ & $121 \cdot 61$ & $121 \cdot 61$ & $121 \cdot 61$ & $121 \cdot 61$ & $121 \cdot 61$ \\
\hline Peas & $100 \cdot 00$ & $100 \cdot 00$ & $100 \cdot 00$ & $100 \cdot 00$ & $100 \cdot 00$ & $100 \cdot 00$ \\
\hline Dicalcium phosphate & $26 \cdot 71$ & $26 \cdot 71$ & $26 \cdot 71$ & $26 \cdot 71$ & $26 \cdot 71$ & $26 \cdot 71$ \\
\hline Blood meal & $21 \cdot 12$ & $21 \cdot 12$ & $21 \cdot 12$ & $21 \cdot 12$ & $21 \cdot 12$ & $21 \cdot 12$ \\
\hline Limestone & $10 \cdot 90$ & $10 \cdot 90$ & $10 \cdot 90$ & $10 \cdot 90$ & $10 \cdot 90$ & $10 \cdot 90$ \\
\hline L-lysine hydrochloride & 2.00 & 2.00 & 2.00 & 2.00 & 2.00 & 2.00 \\
\hline $\mathrm{NaCl}$ & $2 \cdot 00$ & $2 \cdot 00$ & $2 \cdot 00$ & $2 \cdot 00$ & $2 \cdot 00$ & $2 \cdot 00$ \\
\hline Vitamin and mineral premix $†$ & $2 \cdot 00$ & $2 \cdot 00$ & $2 \cdot 00$ & $2 \cdot 00$ & $2 \cdot 00$ & $2 \cdot 00$ \\
\hline DL-methionine & 0.98 & 0.98 & 0.98 & 0.98 & 0.98 & 0.98 \\
\hline L-threonine & 0.94 & 0.94 & 0.94 & 0.94 & 0.94 & 0.94 \\
\hline Soyabean oil & $20 \cdot 0$ & $18 \cdot 75$ & $17 \cdot 5$ & $15 \cdot 0$ & $12 \cdot 5$ & $10 \cdot 0$ \\
\hline CLA-55 & 0.0 & $1 \cdot 25$ & 2.5 & $5 \cdot 0$ & 7.5 & $10 \cdot 0$ \\
\hline
\end{tabular}

Table 1. Composition of experimental diets $(\mathrm{g} / \mathrm{kg})^{*}$

CLA-55, 55\% conjugated linoleic acid.

* The wheat-based diet was formulated to contain $14.3 \mathrm{MJ}$ digestible energy and $175 \mathrm{~g}$ crude protein $/ \mathrm{kg}$ air-dry diet.

†Provided the following nutrients (mg/kg air-dry diet: retinol, 6.4; cholecalciferol, 0.083; $\alpha$-tocopherol, 22; menadione, 0.60; riboflavin, 3.3; nicotinic acid, 16.5; pantothenic acid, 5.5; pyrodoxine, 1.1; biotin, 0.56; choline, 1100; cyanocobalamin, 0.017; Fe, 88; Zn, 55; Mn, 22; Cu, 6.6; I, 0.22; Se, 0.1. 
Pigs were anaesthetised using an intra-muscular injection of Xylazine $(20 \mathrm{mg}$ Xylazine as hydrochloride/ml; Troy Labs Pty. Ltd., Smithfield, NSW) and Ketamine (100 mg Ketamine as hydrochloride/ml; Troy Labs Pty. Ltd.) at 0.05 and $0.1 \mathrm{ml} / \mathrm{kg}$ body weight, respectively. This intramuscular injection was followed by respiratory administration of Isoflourane (Abbott Aust. Pty. Ltd., Kurmel, NSW) to eliminate any further movement. For the final scan before slaughter, Thiopentone (10\% Thiopentone Sodium; Jorox Pty. Ltd., Silverwater, NSW) was administered intravenously at $0.7 \mathrm{ml} / \mathrm{kg}$ body weight in place of Ketamine and Xylazine. Sedated animals were placed prone on the scan table, on their stomach with front and back legs extended caudally. This orientation was used to accommodate the DXA software, which was designed on a basis of a laterally recumbent human subject, i.e. lying on his or her back. Small plastic air-filled bags, undetectable by DXA, were placed between the body and front legs to provide the clearance required by the software to perform accurate analysis.

\section{Slaughter and carcass dual-energy X-ray absorptiometry scans}

After $\mathrm{CO}_{2}$ anaesthesia induced using a commercial $\mathrm{CO}_{2}$ stunning unit, pigs were exsanguinated, had hair removed and were eviscerated. Internal organs were weighed and the gastrointestinal tract emptied and reweighed. Internal organs and empty gastrointestinal tract were then frozen at $-20^{\circ} \mathrm{C}$ for analysis of fat, water and protein content. Carcasses were hung in the chiller from the hindlimbs, and had their front legs tied towards the dorsal end before the onset of rigor. This allowed the correct body positioning required for DXA scanning of carcasses, which was carried out $24 \mathrm{~h}$ post chilling. The carcasses were wrapped in plastic to minimise any moisture loss. Post scanning, the empty carcasses were hung overnight at $4^{\circ} \mathrm{C}$ before being split down the midline and frozen. After freezing, the right side of each carcass and the empty viscera were ground up separately and prepared for chemical analyses (Campbell et al. 1985). DM and tissue moisture was determined by drying samples to constant weight in a force-draught oven at $105^{\circ} \mathrm{C}$. Ash was determined by combustion in a muffle furnace at $600^{\circ} \mathrm{C}$ for $5 \mathrm{~h}$. Protein was determined by Kjeldahl analysis as modified by Helrich (1990) and fat was extracted from freeze-dried samples by chloroform-methanol $(2: 1, \mathrm{v} / \mathrm{v})$ extraction (Folch et al. 1957). Lean tissue was determined from the summation of tissue protein and water. Both halves of the carcass were assumed to be equal in weight and chemical composition and the results were doubled for whole carcass estimation.

\section{Calculation and statistical analysis}

The DXA values obtained in the present study were corrected using regression equations obtained from a larger study involving 150 pigs ranging from 10 to $130 \mathrm{~kg}$ live weight and also scanned using the Hologic QDR4500 DXA (Suster et al. 2000).

The effects of different levels of CLA in the diet on body composition were analysed by ANOVA suitable for a dose response with linear and quadratic effects determined. The model included block, replicate and CLA dose. In addition, comparisons were made between diets with or without CLA. For these analyses the model included block and CLA dose. All analyses were performed using GENSTAT for Windows, version 4.1 (Payne et al. 1993).

\section{Results}

Dietary CLA had no significant effect on average daily gain throughout the present study (Table 2). However, in general there was a linear reduction $(P=0 \cdot 04)$ in feed intake with increasing dose of CLA. This reduction in feed intake was more pronounced over the first 4 weeks of treatment, although a trend towards a linear reduction in feed intake was still evident between weeks 4 and $8(P=0 \cdot 09)$. Consequently, feed conversion efficiency (FCE) was increased by dietary CLA, particularly over the first 4 weeks of the treatment. During the initial 4 weeks of the study there was a quadratic $(P=0.03)$ increase in FCE with the effect maximised at $5 \mathrm{~g}$ CLA-55/kg diet. When all CLA treatments were pooled, including CLA in the diet increased FCE by $8.1 \%(P=0.006)$ over the first 4 weeks while there was no significant change between weeks 4 and $8(P=0 \cdot 26)$.

While live weight at the end of the experiment was unaffected by CLA supplementation, carcass weight increased in a quadratic fashion with the highest carcass weights being observed in pigs fed $5 \mathrm{~g}$ CLA-55/ $\mathrm{kg}$ diet $(83.8 v .86 .6 \mathrm{~kg}$ for pigs fed diets supplemented with 0 and $5 \mathrm{~g} / \mathrm{kg}$, respectively; $P=0.006$ ) (Table 3). Dressing percentage was not affected by the CLA supplementation (Table 3).

Appropriate blocking and allocation to treatments ensured that there were no significant differences in DXAderived estimates of fat, lean, BMC and bone density at the beginning of the experiment (data not shown). The whole-body fat content of pigs fed diets supplemented with CLA decreased in a linear fashion $(P=0.007$ and $P=0.01$ at weeks 4 and 8 , respectively) with increasing level of dietary CLA (Table 4). The proportional reduction in fat content was greatest at week 4 , where in general, CLA-fed pigs tended to have $10.3 \%(P=0.09)$ less fat than the pigs fed the control diets (Table 4). At the highest level of supplementation ( $10 \mathrm{~g} \mathrm{CLA}-55 / \mathrm{kg})$ a $19 \%$ reduction in body fat was observed (17.4v. $14.1 \mathrm{~kg} ; P=0.007)$. After 8 weeks of CLA supplementation, a smaller $(-6 \%)$ reduction in body fat was still evident in CLA-fed pigs but this was not significant $(P=0 \cdot 32)$. Again, the greatest improvement was observed at the highest level of supplementation with CLA$55(-14 \%)$. Significantly linear dose-dependent reductions in fat mass $(P=0.008)$ were also observed in the carcass at the end of the study (Table 4).

Dietary CLA supplementation increased DXA-determined lean tissue composition in a quadratic manner throughout the entire experiment $(P=0.005$ and $P=0.01$ at weeks 4 and 8 , respectively) (Table 4 ). After 4 weeks of treatment, the lean tissue response was maximised in pigs fed diets supplemented with $5 \mathrm{~g}$ CLA-55/kg (56.2 v. $58.6 \mathrm{~kg}$ ). After 8 weeks of feeding, the effect was still maximised at a CLA-55 level around 2.5 to $5.0 \mathrm{~g} / \mathrm{kg}$ 
Table 2. Effect of dietary conjugated linoleic acid (CLA) on growth performance of finishing gilts* (Mean values and standard errors of the difference)

\begin{tabular}{|c|c|c|c|c|c|c|c|c|c|}
\hline \multirow[b]{2}{*}{ Time (weeks)... } & \multicolumn{3}{|c|}{ Rate of gain $(\mathrm{g} / \mathrm{d})$} & \multicolumn{3}{|c|}{ Feed intake $(\mathrm{g} / \mathrm{d})$} & \multicolumn{3}{|c|}{$\begin{array}{l}\text { Feed conversion } \\
\text { efficiency }\end{array}$} \\
\hline & $0-4$ & $4-8$ & $0-8$ & $0-4$ & $4-8$ & $0-8$ & $0-4$ & $4-8$ & $0-8$ \\
\hline \multicolumn{10}{|c|}{ Dose of CLA-55 $(\mathrm{g} / \mathrm{kg}) \dagger$} \\
\hline 0 & 1024 & 816 & 920 & 3083 & 3023 & 3053 & 0.33 & 0.28 & 0.30 \\
\hline 1.25 & 1099 & 853 & 976 & 3062 & 3079 & 3070 & 0.36 & 0.28 & 0.32 \\
\hline 2.5 & 1076 & 870 & 973 & 2895 & 2977 & 2936 & 0.37 & 0.29 & 0.33 \\
\hline $5 \cdot 0$ & 1067 & 899 & 983 & 2811 & 2778 & 2795 & 0.38 & 0.32 & 0.35 \\
\hline 7.5 & 987 & 851 & 919 & 2911 & 2932 & 2922 & 0.34 & 0.29 & 0.31 \\
\hline $10 \cdot 0$ & 974 & 830 & 902 & 2677 & 2758 & 2717 & 0.36 & 0.30 & 0.33 \\
\hline \multicolumn{10}{|l|}{ CLA } \\
\hline No & 1024 & 816 & 920 & 3083 & 3023 & 3053 & 0.33 & 0.28 & 0.30 \\
\hline Yes & 1041 & 861 & 951 & 2871 & 2905 & 2888 & 0.36 & 0.30 & 0.33 \\
\hline SED (dose)‡ & 84 & 83 & 69 & 197 & 188 & 174 & 0.012 & 0.025 & 0.016 \\
\hline SED $(C L A) \S$ & 65 & 65 & 53 & 152 & 146 & 135 & 0.009 & 0.019 & 0.012 \\
\hline \multicolumn{10}{|l|}{ Significance $(P)$} \\
\hline CLA (linear) & 0.19 & 0.96 & 0.43 & 0.04 & 0.09 & 0.04 & 0.36 & 0.30 & 0.21 \\
\hline CLA (quadratic) & 0.40 & 0.32 & 0.26 & 0.85 & 0.82 & 0.82 & 0.03 & 0.21 & 0.07 \\
\hline Control v. CLA & 0.80 & 0.49 & 0.57 & $0 \cdot 18$ & 0.43 & 0.23 & 0.006 & 0.26 & 0.04 \\
\hline
\end{tabular}

${ }^{*}$ For details of diets and procedures, see Table 1 and p. 220.

† CLA nominally contained $55 \%$ fatty acids as CLA isomers.

$¥$ SED between different doses of CLA-55 (five per treatment group).

$\S$ SED of the means between diets containing none (no, $n 5)$ and some (yes, $n$ 25) supplemental CLA-55.

$(67.4 v .70 \cdot 7 \mathrm{~kg})$. The lean tissue composition in pigs fed higher levels $(>5 \mathrm{~g} / \mathrm{kg})$ of CLA-55 was not significantly different from the control pigs. A similar quadratic response $(P=0.009)$ was also observed for DXA-predicted lean content of the carcass (Table 4$)$. There was no significant effect of dietary CLA supplement on DXA-determined empty body and carcass ash content (Table 4).

As expected from the DXA-predicted body composition data, CLA supplementation caused a significant overall linear decrease $(P=0.008)$ in the rate of fat deposition (Table 5). When pooled across dietary treatments, pigs fed CLA deposited $14.5 \%$ less fat than control pigs over the initial period of 4 weeks of supplementation (311 v. $266 \mathrm{~g} / \mathrm{d}$ for control pigs; $P=0 \cdot 07)$. The greatest reduction in fat deposition was observed in pigs fed the highest level of CLA (10 g CLA-55/kg diet) with a $30 \%$ reduction in fat deposition relative to controls $(311$ v. $218 \mathrm{~g} / \mathrm{d}$ for control pigs). The efficacy of CLA in reducing fat deposition diminished during the final 4 weeks of feeding, where pigs fed CLA were not different to the control pigs (287 v. $299 \mathrm{~g} / \mathrm{d}$ for control pigs; $P=0.59$ ). However, the combination of the large reduction in fat deposition in the first 4 weeks of feeding, followed by little change over the final 4 weeks, still resulted in an overall significant $(P=0.008)$ linear reduction in fat deposition in pigs with increasing levels of dietary CLA supplementation over the duration of the experiment.

Over the initial 4 weeks of feeding, the DXA-estimated lean deposition response to CLA supplementation was quadratic $(P=0.02)$ in nature, being maximised at a dietary CLA inclusion rate of $5.0 \mathrm{~g} \mathrm{CLA}-55 / \mathrm{kg}$ (Table 5). However, lean deposition rate during the final 4 weeks of treatment, pooled across CLA-supplemented pigs, was no different from control pigs ( $400 v .420 \mathrm{~g} / \mathrm{d} ; P=0.77)$ with no evidence of a dose response. The magnitude of the response over the first 4 weeks was such that lean deposition rate increased in a quadratic manner $(P=0.017)$ over the entire duration of the experiment, being maximised at a dietary CLA-55 inclusion of between 2.5 and $5 \mathrm{~g} / \mathrm{kg}$ (Table 5).

The estimates of ash (Table 4) and bone mineral density (data not shown) in live animals and carcasses, as determined by DXA, were largely unaffected by CLA

Table 3. Effect of dietary conjugated linoleic acid (CLA) on live weight, carcass weight and dressing at the completion of the study* (Mean values and standard effors of the difference)

\begin{tabular}{|c|c|c|c|}
\hline & $\begin{array}{l}\text { Live weight } \\
(\mathrm{kg})\end{array}$ & $\begin{array}{l}\text { Carcass } \\
(\mathrm{kg})\end{array}$ & $\begin{array}{l}\text { Dressing } \\
\quad(\mathrm{g} / \mathrm{kg})\end{array}$ \\
\hline \multicolumn{4}{|c|}{ Dose of CLA-55 (g/kg diet)† } \\
\hline 0 & $104 \cdot 8$ & $83 \cdot 8$ & 799 \\
\hline $1 \cdot 25$ & $109 \cdot 4$ & $86 \cdot 3$ & 789 \\
\hline 2.5 & $107 \cdot 8$ & $85 \cdot 8$ & 794 \\
\hline $5 \cdot 0$ & $108 \cdot 7$ & $86 \cdot 6$ & 797 \\
\hline $7 \cdot 5$ & $106 \cdot 0$ & $84 \cdot 8$ & 800 \\
\hline $10 \cdot 0$ & $105 \cdot 8$ & $82 \cdot 5$ & 781 \\
\hline \multicolumn{4}{|l|}{ CLA } \\
\hline No & $104 \cdot 8$ & $83 \cdot 8$ & 799 \\
\hline Yes & $107 \cdot 6$ & $85 \cdot 2$ & 792 \\
\hline SED (dose) $\ddagger$ & $2 \cdot 5$ & $1 \cdot 8$ & $9 \cdot 2$ \\
\hline SED (CLA)§ & 1.9 & 1.4 & $7 \cdot 2$ \\
\hline \multicolumn{4}{|l|}{ Significance $(P)$} \\
\hline CLA (linear) & 0.60 & 0.32 & 0.27 \\
\hline CLA (quadratic) & 0.17 & 0.006 & 0.21 \\
\hline Control v. CLA & 0.17 & 0.47 & 0.36 \\
\hline
\end{tabular}

${ }^{*}$ For details of diets and procedures see Table 1 and p. 220.

†CLA nominally contained $55 \%$ fatty acids as CLA isomers.

$¥$ SED between different doses of CLA-55 (five per treatment group).

$\S S E D$ of the means between diets containing none (no, $n 5$ ) and some (yes, $n$ 25) supplemental CLA-55. 
Table 4. Adjusted dual-energy X-ray absorptiometry estimates of fat, lean and ash content of gilts fed dietary conjugated linoleic acid $(\mathrm{CLA})^{*}$

(Mean values and standard errors of the difference)

\begin{tabular}{|c|c|c|c|c|c|c|c|c|c|}
\hline \multirow[b]{2}{*}{ Time (week)... } & \multicolumn{3}{|c|}{ Fat mass $(\mathrm{kg})$} & \multicolumn{3}{|c|}{ Lean mass $(\mathrm{kg})$} & \multicolumn{3}{|c|}{ Ash mass (kg) } \\
\hline & 4 & 8 & Carcass & 4 & 8 & Carcass & 4 & 8 & Carcass \\
\hline \multicolumn{10}{|c|}{ Dose of CLA-55 ( $\mathrm{g} / \mathrm{kg}$ diet $) \dagger$} \\
\hline 0 & $17 \cdot 4$ & $25 \cdot 5$ & $23 \cdot 0$ & $56 \cdot 2$ & 67.4 & $54 \cdot 5$ & 1.9 & $2 \cdot 3$ & $2 \cdot 0$ \\
\hline 1.25 & $18 \cdot 0$ & $27 \cdot 8$ & $24 \cdot 0$ & $56 \cdot 1$ & $67 \cdot 4$ & $55 \cdot 2$ & $1 \cdot 8$ & $2 \cdot 4$ & 1.9 \\
\hline $2 \cdot 5$ & $15 \cdot 4$ & 23.6 & $20 \cdot 9$ & $58 \cdot 1$ & $70 \cdot 9$ & $58 \cdot 1$ & 1.7 & $2 \cdot 2$ & 1.9 \\
\hline $5 \cdot 0$ & $15 \cdot 1$ & 23.1 & $20 \cdot 1$ & $58 \cdot 6$ & $70 \cdot 7$ & $57 \cdot 7$ & 1.8 & $2 \cdot 4$ & $2 \cdot 0$ \\
\hline 7.5 & $15 \cdot 6$ & 23.5 & $20 \cdot 4$ & $57 \cdot 3$ & $69 \cdot 3$ & $56 \cdot 9$ & 1.9 & $2 \cdot 4$ & 1.9 \\
\hline $10 \cdot 0$ & $14 \cdot 1$ & $22 \cdot 0$ & $18 \cdot 6$ & $54 \cdot 7$ & 65.5 & 53.7 & $1 \cdot 8$ & $2 \cdot 4$ & 1.9 \\
\hline \multicolumn{10}{|l|}{ CLA } \\
\hline No & $17 \cdot 4$ & 25.5 & 23.0 & $56 \cdot 2$ & $67 \cdot 4$ & $54 \cdot 5$ & 1.9 & $2 \cdot 3$ & $2 \cdot 0$ \\
\hline Yes & $15 \cdot 6$ & $24 \cdot 0$ & $20 \cdot 8$ & $57 \cdot 0$ & $68 \cdot 7$ & $56 \cdot 3$ & $1 \cdot 8$ & $2 \cdot 4$ & 1.9 \\
\hline SED (dose)‡ & $1 \cdot 31$ & 1.84 & 1.89 & 1.35 & $2 \cdot 26$ & 1.85 & 0.07 & 0.09 & 0.065 \\
\hline SED $(C L A) \S$ & 1.02 & 1.43 & 1.47 & 1.04 & $1 \cdot 75$ & 1.44 & 0.05 & 0.07 & 0.050 \\
\hline \multicolumn{10}{|l|}{ Significance $(P)$} \\
\hline CLA (linear) & 0.007 & 0.01 & 0.008 & 0.41 & 0.50 & 0.69 & 0.78 & 0.21 & 0.74 \\
\hline CLA (quadratic) & 0.55 & 0.67 & 0.67 & 0.005 & 0.01 & 0.009 & 0.69 & 0.61 & 0.62 \\
\hline Control v. CLA & 0.09 & 0.32 & 0.14 & 0.46 & 0.45 & 0.23 & 0.53 & 0.85 & 0.13 \\
\hline
\end{tabular}

${ }^{*}$ For details of diets and procedures, see Table 1 and p. 220.

†CLA nominally contained $55 \%$ fatty acids as CLA isomers.

$\ddagger$ SED between different doses of CLA-55 (five per treatment group).

$\S$ SED of the means between diets containing none (no, $n 5)$ and some (yes, $n 25)$ supplemental CLA-55.

Table 5. Effect of dietary conjugated linoleic acid (CLA) determined by dual-energy X-ray absorptiometry on daily deposition rate of fat, lean and ash in gilts between weeks 0 and 4,4 and 8 and the overall deposition rates $\left(0-8\right.$ weeks) ${ }^{*}$ (Mean values and standard errors of the difference)

\begin{tabular}{|c|c|c|c|c|c|c|c|c|c|}
\hline \multirow[b]{2}{*}{ Time (week)... } & \multicolumn{3}{|c|}{ Fat $(g / d)$} & \multicolumn{3}{|c|}{ Lean $(g / d)$} & \multicolumn{3}{|c|}{ Ash $(g / d)$} \\
\hline & $0-4$ & $4-8$ & $0-8$ & $0-4$ & $4-8$ & $0-8$ & $0-4$ & $4-8$ & $0-8$ \\
\hline \multicolumn{10}{|c|}{ Dose of CLA-55 ( $\mathrm{g} / \mathrm{kg}$ diet $) \dagger$} \\
\hline 0 & 311 & 287 & 299 & 585 & 400 & 493 & $20 \cdot 2$ & $17 \cdot 4$ & $18 \cdot 8$ \\
\hline 1.25 & 319 & 350 & 334 & 631 & 401 & 516 & $20 \cdot 6$ & $19 \cdot 7$ & $20 \cdot 1$ \\
\hline 2.5 & 277 & 294 & 285 & 655 & 456 & 556 & $18 \cdot 1$ & $15 \cdot 8$ & $17 \cdot 0$ \\
\hline $5 \cdot 0$ & 251 & 285 & 268 & 656 & 434 & 545 & 21.5 & $20 \cdot 6$ & $21 \cdot 0$ \\
\hline 7.5 & 267 & 283 & 275 & 606 & 426 & 516 & $21 \cdot 3$ & 18.5 & $19 \cdot 9$ \\
\hline $10 \cdot 0$ & 218 & 281 & 249 & 550 & 385 & 467 & $19 \cdot 7$ & $21 \cdot 0$ & 20.4 \\
\hline \multicolumn{10}{|l|}{ CLA } \\
\hline No & 311 & 287 & 299 & 585 & 400 & 493 & $20 \cdot 2$ & $17 \cdot 4$ & $18 \cdot 8$ \\
\hline Yes & 266 & 299 & 282 & 620 & 420 & 520 & $20 \cdot 2$ & $19 \cdot 1$ & $19 \cdot 7$ \\
\hline SED (dose)‡ & 30.79 & $27 \cdot 43$ & $25 \cdot 22$ & 43.40 & 49.00 & $35 \cdot 30$ & 1.753 & 1.984 & 1.531 \\
\hline SED (CLA)§ & 23.85 & $21 \cdot 25$ & $19 \cdot 54$ & 33.60 & 37.90 & $27 \cdot 30$ & 1.358 & 1.537 & $1 \cdot 186$ \\
\hline \multicolumn{10}{|l|}{ Significance $(P)$} \\
\hline CLA (linear) & 0.002 & 0.14 & 0.008 & 0.18 & 0.77 & 0.30 & 0.68 & 0.09 & 0.17 \\
\hline CLA (quadratic) & 0.85 & 0.99 & 0.91 & 0.02 & 0.17 & 0.02 & 0.61 & 0.73 & 0.95 \\
\hline Control v. CLA & 0.07 & 0.59 & 0.41 & 0.32 & 0.60 & 0.33 & 0.98 & 0.28 & 0.47 \\
\hline
\end{tabular}

${ }^{*}$ For details of diets and procedures, see Table 1 and p. 220.

†CLA nominally contained $55 \%$ fatty acids as CLA isomers.

$¥$ SED between different doses of CLA-55 (five per treatment group).

$\S$ SED of the means between diets containing none (no, $n 5)$ and some (yes, $n$ 25) supplemental CLA-55.

supplementation. However, the deposition rate of ash tended to increase with increasing levels of dietary CLA between weeks 4 and 8 only (Table 5). There was no overall significant effect on bone deposition rate over the entire duration of the experiment $(P=0 \cdot 17)$.

Chemically determined carcass water composition increased linearly $(P=0.011)$ with increasing dietary supplementation of CLA (Table 6). While there was a trend towards a linear increase $(P=0 \cdot 09)$ in carcass protein content with increasing CLA, overall difference between the chemical protein content of control pigs and that of the CLA pigs was not significant $(P=0.54)$. Chemically determined carcass fat decreased linearly $(P=0.008)$ with increasing dietary CLA content (Table 6). At the highest level of CLA inclusion, carcass fat content was decreased by approximately $43 \mathrm{~g} / \mathrm{kg}(-15 \%)$. Carcass ash content 
Table 6. Effect of dietary conjugated linoleic acid (CLA) on chemical carcass composition at week 8 of the treatment* (Mean values and standard errors of the difference)

\begin{tabular}{|c|c|c|c|c|c|c|}
\hline & Protein $(\mathrm{g} / \mathrm{kg})$ & Water (g/kg) & Water:protein & Ash (g/kg) & Fat $(\mathrm{g} / \mathrm{kg})$ & Fat:protein \\
\hline \multicolumn{7}{|c|}{ Dose of CLA-55 ( $/ \mathrm{kg}$ diet)† } \\
\hline 0 & 159 & 517 & $3 \cdot 26$ & $26 \cdot 2$ & 293 & 1.85 \\
\hline 1.25 & 151 & 516 & 3.44 & $25 \cdot 2$ & 303 & 2.05 \\
\hline $2 \cdot \overline{5}$ & 164 & 547 & 3.33 & $23 . \overline{7}$ & 261 & 1.61 \\
\hline $5 \cdot 0$ & 168 & 570 & 3.39 & $25 \cdot 9$ & 232 & 1.39 \\
\hline 7.5 & 163 & 545 & 3.35 & $25 \cdot 8$ & 262 & 1.61 \\
\hline $10 \cdot 0$ & 165 & 554 & 3.37 & $27 \cdot 1$ & 250 & 1.52 \\
\hline \multicolumn{7}{|l|}{ CLA } \\
\hline No & 159 & 517 & 3.26 & $26 \cdot 2$ & 293 & 1.85 \\
\hline Yes & 162 & 546 & 3.38 & $25 \cdot 6$ & 261 & 1.64 \\
\hline SED (dose)‡ & 5.9 & $16 \cdot 2$ & 0.131 & 1.36 & $19 \cdot 8$ & 0.183 \\
\hline SED (CLA)§ & 4.6 & $12 \cdot 6$ & 0.102 & 1.06 & $15 \cdot 3$ & 0.142 \\
\hline \multicolumn{7}{|l|}{ Significance $(P)$} \\
\hline CLA (linear) & 0.09 & 0.01 & 0.71 & 0.18 & 0.008 & 0.01 \\
\hline CLA (quadratic) & 0.26 & 0.04 & 0.58 & $0 \cdot 17$ & 0.06 & $0 \cdot 11$ \\
\hline Control v. CLA & 0.54 & 0.03 & 0.24 & 0.57 & 0.05 & 0.14 \\
\hline
\end{tabular}

${ }^{*}$ For details of diets and procedures, see Table 1 and p. 220.

† CLA nominally contained $55 \%$ fatty acids as CLA isomers.

$\ddagger$ SED between different doses of CLA-55 (five per treatment group).

§SED of the means between diets containing none (no, $n 5)$ and some (yes, $n$ 25) supplemental CLA-55.

was not affected by dietary CLA. Fat:protein in the carcass decreased linearly $(P=0 \cdot 01)$ with increasing dietary CLA. There were no significant differences in water:protein in the carcass.

As expected from the chemically predicted body composition data, the chemical fat deposition rates determined by the slaughter-balance technique showed a similar linear reduction $(P=0 \cdot 01)$ with the increasing level of dietary CLA in the feed (Table 7). At the highest dietary CLA content, there was an $84 \mathrm{~g} / \mathrm{d}$ decrease in fat deposition (322 v. $238 \mathrm{~g} / \mathrm{d}$ ). While the effect of dietary CLA supplementation on chemical protein deposition was variable, there was a significant quadratic effect $(P=0.02)$, with the response being maximised at a dietary CLA-55 content of $5 \mathrm{~g} / \mathrm{kg}$ (Table 7). However, there was no overall difference in protein deposition rate between control and all CLA-supplemented pigs (138 v. $141 \mathrm{~g} / \mathrm{d} ; P=0.69)$. Similarly, the water deposition rate determined by the slaughter-balance technique showed a quadratic response to the CLA level supplemented in the diet $(P=0.003$; Table 7) with the response again maximised at $5.0 \mathrm{~g}$ CLA-55/kg diet. There was no effect of dietary CLA on chemical ash deposition.

The efficacy of using DXA to measure effects of CLA

Table 7. Effect of dietary conjugated linoleic acid (CLA) on tissue deposition rates determined by the slaughter-balance technique at week 8 of the treatment ${ }^{*}$

(Mean values and standard errors of the difference)

\begin{tabular}{lccccc}
\hline & Protein $(\mathrm{g} / \mathrm{d})$ & Water $(\mathrm{g} / \mathrm{d})$ & Lean $(\mathrm{g} / \mathrm{d})$ & Ash $(\mathrm{g} / \mathrm{d})$ & Fat $(\mathrm{g} / \mathrm{d})$ \\
\hline Dose of CLA-55 $(\mathrm{g} / \mathrm{kg}$ diet) $\dagger$ & 138 & & & & \\
$\quad 0$ & 129 & 420 & 558 & 19.4 & 322 \\
1.25 & 148 & 428 & 557 & 19.7 & 348 \\
2.5 & 153 & 519 & 627 & 15.9 & 285 \\
5.0 & 144 & 471 & 672 & 19.9 & 239 \\
7.5 & 130 & 431 & 561 & 18.8 & 278 \\
10.0 & 138 & 420 & 558 & 19.7 & 238 \\
CLA & 141 & 466 & 607 & 18.4 & 322 \\
$\quad$ No & 9.8 & 32.1 & 39.1 & 1.72 & 38.9 \\
Yes & 7.6 & 24.9 & 30.3 & 1.33 & 30.1 \\
SED (dose) & & & & & \\
SED (CLA)§ & 0.94 & 0.47 & 0.56 & 0.59 & 0.01 \\
Significance $(P)$ & 0.02 & 0.003 & 0.003 & 0.97 & 0.41 \\
CLA (linear) & 0.69 & 0.08 & 0.12 & 0.46 & 0.15 \\
CLA (quadratic) & & & & & \\
Control v. CLA & & & & & \\
\hline
\end{tabular}

* For details of diets and procedures, see Table 1 and p. 220

† CLA nominally contained $55 \%$ fatty acids as CLA isomers.

$\ddagger$ SED between different doses of CLA-55 (five per treatment group).

$\S$ SED of the means between diets containing none (no, $n$ 5) and some (yes, $n$ 25) supplemental CLA-55. 
Table 8. Comparison of the final values (week 8) for dual-energy X-ray absorptiometry (DXA), DXA-adjusted values (DXA-adj) and chemical analysis (CHEM) of body composition*

(Mean values and standard deviations for thirty-five pigs)

\begin{tabular}{|c|c|c|c|c|c|c|c|c|}
\hline \multirow[b]{2}{*}{ Variable } & \multicolumn{2}{|c|}{ CHEM } & \multicolumn{2}{|c|}{ DXA } & \multicolumn{2}{|c|}{ DXAadj† } & \multicolumn{2}{|c|}{ Significance $(P)$} \\
\hline & Mean & SD & Mean & SD & Mean & SD & CHEM v. DXA & CHEM $v$. DXAad \\
\hline \multicolumn{9}{|c|}{ Chemical analysis of carcass (including viscera) $v$. DXA live animal estimates } \\
\hline Fat $(\mathrm{kg})$ & $25 \cdot 55$ & 3.94 & 19.42 & 2.94 & 24.23 & 3.87 & $<0.001$ & $<0.001$ \\
\hline Lean $(\mathrm{kg})$ & $68 \cdot 24$ & $4 \cdot 19$ & 80.57 & 4.76 & 68.52 & 3.95 & $<0.001$ & 0.51 \\
\hline $\mathrm{BMC}(\mathrm{kg})$ & 2.51 & 0.16 & 1.81 & 0.15 & 2.35 & 0.17 & $<0.001$ & $<0.001$ \\
\hline \multicolumn{9}{|c|}{ Chemical analysis of empty carcass $v$. DXA empty carcass estimates } \\
\hline Fat $(\mathrm{kg})$ & 21.38 & 3.71 & $18 \cdot 22$ & 3.00 & $21 \cdot 17$ & 3.66 & $<0.001$ & 0.51 \\
\hline Lean $(\mathrm{kg})$ & $56 \cdot 20$ & 3.66 & 59.89 & 3.53 & $56 \cdot 02$ & 3.35 & 0.002 & 0.63 \\
\hline $\mathrm{BMC}(\mathrm{kg})$ & 2.05 & 0.15 & 1.72 & 0.10 & 1.94 & 0.11 & $<0.001$ & $<0.001$ \\
\hline
\end{tabular}

BMC, bone mineral content.

${ }^{*}$ For details of procedures, see p. 220.

†DXA values were adjusted using equations from Suster et al. (2000).

on body composition were tested by comparing chemically determined body composition directly against the estimates of body composition generated by the internal algorithms (Table 8). An additional comparison was then made after the outputs from the DXA machine were corrected using regression equations relating chemical composition to DXA estimates generated in a larger ( $n$ 150) group of pigs of varying live weight and body composition (Suster et al. 2000). The whole animal and carcass DXA-predicted values for fat, lean and ash compared with those measured on the same animals directly by chemical analysis were all significantly different $(P<0.001)$ with fat and ash being underestimated and lean being overestimated. The greatest differences were in the live animal estimations of lean, which was probably due to presence of water in the gut lumen detected as being associated with lean tissue. Hence, DXA estimation of lean in the empty body measurement was much closer to the chemically determined values, although they were still significantly different $(P=0 \cdot 002)$. The DXA predictions adjusted using the regression equations from DXA validation studies (Suster et al. 2000) essentially corrected the overestimations and underestimations made by DXA algorithms. Although whole-body fat and both wholebody and carcass ash were still significantly different after correction, the numerical differences were quite small. The adjusted DXA estimates of carcass fat, lean and BMC done on the live animal averaged 94.8, 100.4 and $93.6 \%$ of the chemically determined values, respectively, while similar comparisons of DXA estimates determined on the empty carcass were 99.0, 99.7 and 94.6, respectively (Table 8).

The correlation $(R 0.86)$ between the fat deposition rate estimated by the slaughter-balance technique $v$. the DXA estimations of fat deposition illustrates that the two methods are measuring the same thing (Fig. 1). The slope of the relationship is also close to unity (1.07), although the intercept is significantly different than zero indicating a $20 \mathrm{~g}$ bias towards the chemical prediction.

Dietary CLA supplementation did not appear to have any significant effect on the weights of any of the major internal organs and tissues (Table 9).

\section{Discussion}

While there were no significant changes in growth rate as a result of CLA supplementation, feed intake decreased in a linear fashion $(P=0.04)$ as the concentration of CLA in the diet increased. Consequently, there was a significant improvement in FCE for CLA-fed pigs $(+7.9 \% ; P=0.045)$. The significant effects in FCE were mostly due to improvements during the first 4 weeks of the treatment interval where FCE was increased by $8 \% \quad(P=0.006)$. Other workers have also observed similar small improvements in FCE in pigs supplemented with dietary CLA (Dugan et al. 1997; Thiel-Cooper et al. 2001) and our earlier work demonstrated that FCE was increased by $6.4 \%$ by CLA supplementation (Ostrowska et al. 1999).

The present study confirms the findings from our earlier reports showing that dietary CLA reduces fat deposition while increasing lean deposition in finisher pigs (Dunshea et al. 1998; Ostrowska et al. 1999). Using DXA to measure composition has shown that the response was most pronounced during the first 4 weeks of CLA supplementation with very little response thereafter. For example, fat deposition during the first 4 weeks was minimised at the

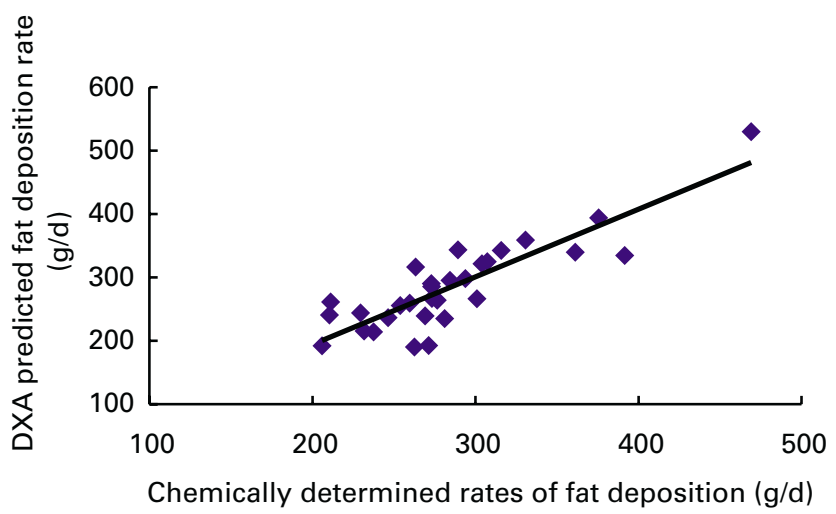

Fig. 1. Correlation between body fat deposition rates determined by slaughter-balance techniques dual-energy $\mathrm{X}$-ray absorptiometry (DXA)-predicted fat deposition rates $(Y=1.07 X-19.6, \mathrm{R} 0.86$, $P<0.001)$. 
Table 9. Effect of dietary conjugated linoleic acid (CLA) on visceral organ weights at week 8 of the treatment* (Mean values and standard errors of the difference)

\begin{tabular}{|c|c|c|c|c|c|c|c|c|c|}
\hline \multirow[b]{2}{*}{ Organ... } & \multicolumn{9}{|c|}{ Weight (g) } \\
\hline & Liver & Heart & Kidneys & Lungs & Stomach & Small intestine & Caecum & Large intestine & Spleen \\
\hline \multicolumn{10}{|c|}{ Dose of CLA-55 ( $\mathrm{g} / \mathrm{kg}$ diet $) \dagger$} \\
\hline 0 & 1757 & 333 & 339 & 630 & 601 & 1377 & 220 & 1851 & 154 \\
\hline $1 \cdot 25$ & 1743 & 337 & 302 & 535 & 570 & 1282 & 199 & 1558 & 134 \\
\hline $2 \cdot 5$ & 1814 & 346 & 326 & 554 & 597 & 1316 & 226 & 1693 & 160 \\
\hline $5 \cdot 0$ & 1782 & 380 & 360 & 536 & 553 & 1279 & 221 & 1828 & 143 \\
\hline $10 \cdot 0$ & 1718 & 353 & 353 & 577 & 542 & 1214 & 207 & 1669 & 146 \\
\hline \multicolumn{10}{|l|}{ CLA } \\
\hline No & 1757 & 333 & 339 & 630 & 601 & 1377 & 220 & 1851 & 154 \\
\hline Yes & 1787 & 356 & 336 & 574 & 565 & 1264 & 210 & 1670 & 142 \\
\hline SED (dose)‡ & 111 & $20 \cdot 7$ & $24 \cdot 2$ & 85.6 & $41 \cdot 7$ & 104 & $24 \cdot 3$ & 157 & $15 \cdot 6$ \\
\hline SED (CLA)§ & 86 & $16 \cdot 0$ & $18 \cdot 7$ & $66 \cdot 3$ & $32 \cdot 3$ & 80 & $18 \cdot 8$ & 121 & $12 \cdot 1$ \\
\hline \multicolumn{10}{|l|}{ Significance $(P)$} \\
\hline CLA (quadratic) & 0.29 & 0.09 & 0.93 & 0.64 & 0.86 & 0.81 & 0.82 & 0.91 & 0.62 \\
\hline Control v. CLA & 0.73 & 0.17 & 0.89 & 0.41 & 0.27 & 0.18 & 0.59 & 0.15 & 0.37 \\
\hline
\end{tabular}

${ }^{*}$ For details of diets and procedures, see Table 1 and p. 220.

†CLA nominally contained $55 \%$ fatty acids as CLA isomers.

¥SED between different doses of CLA-55 (five per treatment group).

$\S$ SED of the means between diets containing none (no, $n$ 5) and some (yes, $n$ 25) supplemental CLA-55.

highest level of CLA supplementation, with pigs receiving $10 \mathrm{~g}$ CLA-55/kg diet depositing $93 \mathrm{~g}$ less fat $/ \mathrm{d}$ than pigs fed the unsupplemented diets. However, over the final 4 weeks, fat deposition in the same group of pigs was only $6 \mathrm{~g} / \mathrm{d}$ less than that of control pigs. Despite this, the combination of large differences in fat deposition rates over the first 4 weeks of feeding with much smaller differences during the following weeks of CLA supplementation still resulted in an overall significant decrease in fat deposition. At the end of the experiment, pigs fed the highest level of CLA averaged $50 \mathrm{~g} / \mathrm{d}$ less fat accretion than control pigs $(P=0.008)$. In a previous experiment, the reduction in fat deposition rate at the highest level of supplementation $(10 \mathrm{~g} / \mathrm{kg})$ was found to be much greater $(-86 \mathrm{~g} / \mathrm{d}$; Ostrowska et al. 1999). However, in the latter study the fat deposition rates were determined from the difference in body composition found in pig carcasses at the end of the experiment compared with a representative group of pigs slaughtered at the beginning of the experiment (slaughter-balance technique). The present study also provided a very similar estimate of reduction in fat deposition when estimated using the slaughter-balance technique $(-84 \mathrm{~g} / \mathrm{d})$. However, there is a very high internal consistency in fat deposition responses both between studies using the same technique and within a study using different techniques (Fig. 1).

The DXA-determined lean deposition rates were maximised during the first 4 weeks (0-4 weeks) of dietary CLA supplementation with no significant effects being observed in the subsequent 4 weeks (4-8 weeks) of the study. The DXA-determined lean tissue deposition rates were maximised at between 2.5 and $5.0 \mathrm{~g}$ CLA-55/kg diet, similar to that observed by Ostrowska et al. (1999). The chemical analyses in the present study, as well as our earlier work (Ostrowska et al. 1999), indicate that there was very little change in protein deposition, and that the change in lean tissue was due predominantly to an increase in water deposition. Since DXA technology estimates lean tissue from body water content, an increase in tissue hydration will be ascribed to an increase in lean tissue. Although there was no significant effect of CLA on water:protein in the present study, previously we have shown a significant increase in water:protein of a similar magnitude to that observed here (Ostrowska et al. 1999). Therefore, some care should be made in interpreting DXA-determined changes in body composition when there are also resultant changes in tissue hydration. It is also worth noting that the lean tissue deposition response to CLA supplementation was quadratic, being maximised at between 2.5 and $5.0 \mathrm{~g} \mathrm{CLA}-55 / \mathrm{kg}$, whereas the fat deposition response was linear. The different dose responses to CLA will need to be taken into account when determining the most cost-effective dose to feed on-farm.

The genotype used in the present study and that of Ostrowska et al. (1999) was of moderate fatness and gilts were utilised in these studies as they tend to deposit more fat than boars (Dunshea et al. 1993). However, the responses to CLA may vary with genetic propensity for fat or lean accretion. CLA response may also vary between gilts and barrows. For example, the benefits of a similar CLA preparation to that used in the present study appeared to be less pronounced in lean genotypes, as was observed in an on-farm study with boars and gilts (Dunshea et al. 2002). Also, the response varied between farms and/or genotypes and was greater in gilts than in boars (Dunshea et al. 2002). However, smaller but significant reductions in carcass P2 $(-1.0 \mathrm{~mm})$ and carcass fat $(-7 \mathrm{~g} / \mathrm{kg})$ were recorded under commercial conditions at dietary CLA 
concentrations as little as $2 \cdot 2 \mathrm{~g}$ total $\mathrm{CLA} / \mathrm{kg}$. A recent short communication (Heckart et al. 2000) reported that feeding CLA decreased expression of fatty acid synthase in medium-lean line pigs and increased $(P<0.01)$ expression in the high-lean pigs. The expression of stearoyl-CoA desaturase was decreased $(P<0.01)$ in mediumlean line pigs and tended $(P=0.08)$ to increase in the high-lean line group. These data suggest that CLA acts to modify expression of lipogenic genes in pigs that have not been selected for low fat deposition rates (Heckart et al. 2000). Furthermore, others have shown that supplementation of CLA does not alter backfat thickness in lactating sows (Harrell et al. 2000; Poulos et al. 2000). Therefore, it is possible that there are differences between the adolescent and adult animals and their response to CLA. There are data to suggest that CLA may affect growing animals differently from adults by depressing body fat accumulation via a reduction in preadipocyte number when given during periods of growth (Satory \& Smith, 1999). In human studies, with weightstable adults with stable body composition, no reduction in fat content was observed as a result of CLA $(65 \%$ purity) supplementation at $3 \mathrm{~g} / \mathrm{d}$ (Medina et al. 2000; Zambell et al. 2000). However, a study with obese or overweight volunteers reported significant reductions in body fat at levels of 3.4 and $6.8 \mathrm{~g}$ CLA (75\% purity)/d (Blankson et al. 2000) and significant reductions in abdominal fat at $4 \mathrm{~g}$ CLA $(75 \%$ purity)/d (Riserus et al. 2001). If CLA does not stimulate lipolysis then one would expect to see no reduction in body fat already present in weightstable adults. However, if it worked by inhibiting fat accretion, then CLA would work in adults providing they exercised or dieted so that the CLA could inhibit regain of fat. Data from our previous study in a pig model showed that the reduced fat accretion in pigs fed CLA was largely attributed to a reduced rate of lipogenesis from preformed fatty acids and possibly to a lesser extent due to increased lipolysis (Ostrowska et al. 2002).

The isomer thought to be responsible for the reduction in lipid accretion and storage in laboratory animals is the trans, cis-10,12; (de Deckere et al. 1999; Park et al. 1999a). This isomer was the most predominant in the CLA mixture used in the present study. The trans, cis-10,12 isomer was found to affect key enzymes involved in fatty acid uptake and transport. Some of the responses included a reduction in lipoprotein lipase activity, and lower levels of triacylglycerol and glycerol in adipocyte cells (Lin et al. 1999; Park et al. 1999b; Wang et al. 1999). Recently, the isomer was shown to markedly reduce the expression of genes encoding for two key enzymes, acetyl CoA carboxylase and fatty acid synthetase, involved in de novo fatty acid synthesis in dairy cows (Baumgard et al. 2002). Furthermore, the expression encoding for the enzyme that hydrolyses circulating triacylglycerol (lipoprotein lipase) as well as proteins involved in intracellular trafficking of fatty acids (fatty acid-binding protein) were also significantly reduced (Baumgard et al. 2002).

Further additional information gained from the present study was the effect of CLA on BMC and density. In recent studies with chicks and rats, CLA was shown to increase the rate of bone formation as indicated by an increase in percentage of ash in the body ( $\mathrm{Li} \&$ Watkins, 1998; Park \& Pariza, 1998; de Deckere et al. 1999; Watkins \& Seifert, 2000). In the present study, dietary CLA supplementation had no effect on the rate of ash deposition as determined by the slaughter-balance technique. The DXA estimates of bone density and content, both of which are free from assumptions regarding levels of tissue hydration (Haderslev et al. 1999), confirmed that CLA had little effect on these measures in pigs.

Despite widespread use of non-esterified fatty acid or methyl ester forms of CLA in research diets there is no evidence of the differences in the digestibility of different preparations. Non-esterified fatty acids are known to be less digestible in pigs when compared with triacylglycerols (Whittemore, 1993). Therefore the reduction in the feed intake in the CLA-fed pigs could be partially attributed to the acceptability of non-esterified fatty acids as lipid source. However, the growth rate was unaffected by CLA supplementation indicating that CLA non-esterified fatty acids were digested and metabolised sufficiently to maintain growth. Furthermore, the CLA was assimilated very efficiently into the tissue of pigs and in a dose-dependent manner (E Ostrowska, unpublished results). Today, the commercially available CLA is present in methyl esters of fatty acids. Lipids in this form are not found in natural diets and it is possible that esterified fatty acids could be less digestible than triacylglycerols or even non-esterified fatty acids. The ability of pigs to digest and assimilate these different forms of CLA needs to be more thoroughly investigated.

In conclusion, use of DXA technology has shown that the greatest reductions in fat deposition rates and increase in lean tissue deposition rates were achieved in the initial 4 weeks of CLA supplementation. This in turn suggests that the small additional benefits from long-term feeding with CLA may not necessarily be cost-effective. Additional factors including genetics, sex and age of the animal and the CLA isomer composition and its form probably play a vital role in determining the final outcome.

\section{References}

Anonymous (1997) Australian Code of Practice for the Care and Use of Animals for Scientific Purposes, 6th ed. National Health and Medical Research. Melbourne, Australia: CSIRO Publications.

Baumgard LH, Matitashvili E, Corl BA, Dwyer DA \& Bauman DE (2002) Trans-10,cis-12 CLA decreases lipogenic rates and expression of genes involved in milk lipid synthesis in dairy cows. Journal of Dairy Science 85, 2155-2163.

Blankson H, Stakkestad JA, Fagertun H, Thom E, Wadstein J \& Gudmundsen O (2000) Conjugated linoleic acid reduces body fat mass in overweight and obese humans. Journal of Nutrition 130, 2943-2948.

Campbell RG, Taverner MR \& Curic DM (1985) The influence of feeding level on the protein requirement of pigs between 20 and $45 \mathrm{~kg}$. Animal Production 40, 489-496.

Chin SF, Storkson JM, Albright KJ, Cook ME \& Pariza MW (1994) Conjugated linoleic acid is a growth factor for rats as shown by enhanced weight gain and improved feed efficiency. Journal of Nutrition 124, 2344-2349.

Cross RF, Ostrowska E, Muralitharan M \& Dunshea FR (2000) 
Mixed mode retention and the use of competing acid for the Ag-HPLC analysis of underivatized conjugated linoleic acids. Journal of High Resolution Chromatography 23, 317-323.

de Deckere EA, van Amelsvoort JM, McNeill GP \& Jones P (1999) Effects of conjugated linoleic acid (CLA) isomers on lipid levels and peroxisome proliferation in the hamster. British Journal of Nutrition 82, 309-317.

DeLany JP, Blohm F, Truett AA, Scimeca JA \& West DB (1999) Conjugated linoleic acid rapidly reduces body fat content in mice without affecting energy intake. American Journal of Physiology 276, R1172-R1179.

Dugan ME, Aalhus JL, Schaefer AL \& Kramer JK (1997) The effect of conjugated linoleic acid on fat to lean repartitioning and feed conversion in pigs. Canadian Journal of Animal Science 77, 723-725.

Dunshea FR, King RH, Campbell RG, Sainz RD \& Kim YS (1993) Interrelationships between sex and ractopamine on protein and lipid deposition in rapidly growing pigs. Journal of Animal Science 71, 2919-2930.

Dunshea FR, Ostrowska E, Luxford B, Smits RJ, Campbell RG, D'Souza DN \& Mullan BP (2002) Dietary conjugated linoleic acid can decrease backfat in pigs housed under commercial conditions. Asian-Australasian Journal of Animal Science 15, 1011-1017.

Dunshea FR, Ostrowska E, Muralitharan M, Cross RF, Bauman DE, Pariza M \& Skarie C (1998) Dietary conjugated linoleic acid decreases backfat in growing gilts. Journal of Animal Science 76, 131.

Folch J, Lees M \& Sloane-Stanley GH (1957) A simple method for the isolation and purification of total lipids from animal tissues. Journal of Biological Chemistry 226, 497-509.

Haderslev KV, Svendsen OL \& Staun M (1999) Does paracentesis of ascites influence measurements of bone mineral or body composition by dual-energy X-ray absorptiometry? Metabolism 48, 373-377.

Harrell RJ, Phillips O, Jerome DL, Boyd RD, Dwyer DA \& Bauman DE (2000) Effects of conjugated linoleic acid on milk composition and baby pig growth in lactating sows. Journal of Animal Science 78, Suppl. 1, 137.

Heckart ML, Eggert JM, Schinckel AP, Mills SE \& Donkin SS (2000) Differential action of dietary conjugated linoleic acids (CLA) on lipogenic gene expression in adipose tissue of two porcine genotypes. Journal of Animal Science 78, Suppl. 1, 179.

Helrich K (1990) Official Methods of Analysis, 15th ed. Arlington, VA: Association of Official Analytical Chemists Inc.

Li Y \& Watkins BA (1998) Conjugated linoleic acids alter bone fatty acid composition and reduce ex vivo prostaglandin E2 biosynthesis in rats fed n-6 or n-3 fatty acids. Lipids 33, 417-425.

Lin TY, Lin CW \& Lee CH (1999) Conjugated linoleic acid concentration as affected by lactic cultures and added linoleic acid. Food Chemistry 67, 1-5.

Lukaski HC, Marchello MJ, Hall CB, Schafer DM \& Siders WA (1999) Soft tissue composition of pigs measured with dual x-ray absorptiometry: comparison with chemical analyses and effects of carcass thicknesses. Nutrition 15, 697-703.

Medina EA, Horn WF, Keim NL, Havel PJ, Benito P, Kelley DS, Nelson GJ \& Erickson KL (2000) Conjugated linoleic acid supplementation in humans: effects on circulating leptin concentrations and appetite. Lipids 35, 783-788.

Mitchell AD, Conway JM \& Scholz AM (1996) Incremental changes in total and regional body composition of growing pigs measured by dual-energy x-ray absorptiometry. Growth, Development and Aging 60, 95-105.

Mitchell AD, Scholz AM \& Conway JM (1998) Body composition analysis of small pigs by dual-energy x-ray absorptiometry. Journal of Animal Science 76, 2392-2398.
Ostrowska E, Cross RF, Muralitharan M, Bauman DE \& Dunshea FR (2002) Effects of dietary fat and conjugated linoleic acid on plasma metabolite concentrations and metabolic responses to homeostatic signals in pigs. British Journal of Nutrition 88, 625-634.

Ostrowska E, Dunshea FR, Muralitharan M \& Cross RF (2000) Comparison of silver-ion high-performance liquid chromatographic quantification of free and methylated conjugated linoleic acids. Lipids 35, 1147-1153.

Ostrowska E, Muralitharan M, Cross RF, Bauman DE \& Dunshea FR (1999) Dietary conjugated linoleic acids increase lean tissue and decrease fat deposition in growing pigs. Journal of Nutrition 129, 2037-2042.

Pariza MW, Park Y \& Cook ME (2001) The biologically active isomers of conjugated linoleic acid. Progress in Lipid Research 40, 283-298.

Park Y, Albright KJ, Liu W, Cook ME \& Pariza MW (1995) Dietary conjugated linoleic acid (CLA) reduces body fat content and isomers of CLA are incorporated into phospholipid fraction. In IFT Annual Meeting, p. 183. Madison, WI: University of Wisconsin, Department of Food Microbiology and Toxicology.

Park Y, Albright KJ, Storkson JM, Liu W, Cook ME \& Pariza MW (1999a) Changes in body composition in mice during feeding and withdrawal of conjugated linoleic acid. Lipids 34, 243-248.

Park Y \& Pariza MW (1998) Evidence that commercial calf and horse sera can contain substantial amounts of trans-10, cis-12 conjugated linoleic acid. Lipids 33, 817-819.

Park Y, Storkson JM, Albright KJ, Liu W \& Pariza MW (1999b) Evidence that the trans-10, cis-12 isomer of conjugated linoleic acid induces body composition changes in mice. Lipids $\mathbf{3 4}$, 235-241.

Payne RW, Lane PW \& Genstat 5 Committee (1993) Genstat 5 Reference Manual. Oxford, UK: Oxford Science Publications.

Poulos SP, Azain MJ \& Hausman GJ (2000) In utero dietary conjugated linoleic acid (CLA) alters body composition and growth rate in new-born pigs. Journal of Animal Science 78, Suppl. 1, 137.

Riserus U, Berglund L \& Vessby B (2001) Conjugated linoleic acid (CLA) reduced abdominal adipose tissue in obese middle-aged men with signs of the metabolic syndrome: a randomised controlled trial. International Journal of Obesity and Related Metabolic Disorders 25, 1129-1135.

Satory DL \& Smith SB (1999) Conjugated linoleic acid inhibits proliferation but stimulates lipid filling of murine 3T3-L1 preadipocytes. Journal of Nutrition 129, 92-97.

Standing Committee on Agriculture (1987) Feeding Standards for Australian Livestock. Pigs. Melbourne, Australia: CSIRO Publications.

Suster D, Leury BJ, Hofmeyr CD, Wark JD \& Dunshea FR (2001) Dual energy X-ray absorptiometry predicts lean yield in the half carcass and primal cuts of the pig. In Manipulating Pig Production, vol. VIII, p. 81 [PD Cranwell, editor]. Werribee, Australia: Australasian Pig Science Association.

Suster D, Leury BJ, Wark JD, Kerton DJ, Ostrowska E \& Dunshea FR (2000) Dual energy x-ray absorptiometry to predict whole body and carcass composition in pigs. Journal of Animal Science 78, 145.

Thiel-Cooper RL, Parrish FC Jr, Sparks JC, Wiegand BR \& Ewan RC (2001) Conjugated linoleic acid changes swine performance and carcass composition. Journal of Animal Science 78, $1821-1828$.

Wang MY, Lee Y \& Unger RH (1999) Novel form of lipolysis induced by leptin. Journal of Biological Chemistry 274, $17541-17544$.

Watkins BA \& Seifert MF (2000) Conjugated linoleic acid and 
bone biology (In Process Citation). Journal of the American College of Nutrition 19, 478S-486S.

Whigham LD, Cook ME \& Atkinson RL (2000) Conjugated linoleic acid: implications for human health. Pharmacological Research 42, 503-510.

Whittemore C (1993) Value of fats in pig diets. In The Science and Practice of Pig Production, pp. 323-328. London: Longman Scientific and Technical.

Zambell KL, Keim NL, Van Loan MD, Gale B, Benito P, Kelley DS \& Nelson GJ (2000) Conjugated linoleic acid supplementation in humans: effects on body composition and energy expenditure. Lipids 35, 777-782. 